\title{
ВЛИЯНИЕ ВТОРИЧНЫХ ПРОЦЕССОВ НА КОЛИЧЕСТВЕННОЕ СООТНОШЕНИЕ ТЯЖЕЛЫХ АЛЛОТИГЕННЫХ МИНЕРАЛОВ
}

Характер и количественные соотношения тяжелых аллотигенных минералов часто служат важной основой решения палеогеографических и стратиграфических задач. Как известно, наблюдаемые в осадочных породах соотношения минералов - результат действия многих факторов. Начальный минеральный состав исходных пород преобразуется уже в коре выветривания. Здесь за счет выветривания заметно сокращается число химически менее устойчивых минералов, в частности полевых шпатов (особенно плагиоклазов), биотита, амфиболов, пироксенов, эпидота, титанита, которые увеличивают относительное количество устойчивых минералов, в первую очередь, кварца, черных рудных минералов и циркона. Содержание апатита в одних случаях уменьшается, в других увеличивается (Goldich, 1938; Казанский, 1969; Meyer, 1976). В дальнейшем количество малоустойчивых минералов, особенно минералов с хорошей спайностью, уменьшается при транспортировке, осаждении и переотложении кластического материала. В результате этого существенно возрастает относительное количество циркона, граната и особенно турмалина (Казанский, 1969, 1976). Большое влияние на формирование минерального состава оказывают процессы селективной сортировки. Например, гранат и корунд сосредоточиваются в прибрежной полосе, турмалин, роговые обманки и другие относительно легкие минералы уносятся дальше (Окнова, 1972; Flores, Shidler, 1978).

Количественное соотношение аллотигенных минералов изменяется и в постседиментационный период истории отложений. Роль и факторы последних преобразований пока определены неоднозначно (Andel, 1959; Коссовская, 1962; Копелиович, 1965; Morton, 1979). Обычно подчеркивается тенденция убывания малоустойчивых минералов в более древних отложениях или в породах более глубокого захоронения. Исследований, основывающихся на конкретных детально изученных разрезах в настоящее время немного (Hubert, Reed, 1978).

Среднедевонский разрез Прибалтики с переслаиванием рыхлых и сцементированных пород (песчаников, алевролитов, глин, домеритов и доломитов), обладающих различной способностью хранения в них минералов в постседиментационный период, может дать ценную информацию для оценки роли некоторых постседиментационных процессов. Поэтому он нами и взят под исследования и первые результаты этой работы излагаются ниже.

Рассматриваемый разрез начинается снизу сравнительно мощным комплексом рыхлых песчано-алевритовых отложений, залегающим на карбонатных породах ордовика или силура (Резекненский, Пярнуский горизонты). В этом комплексе встречаются лишь редкие прослои глин и карбонатных пород (рис. 2). Средняя часть изучаемого разреза представлена карбонатными отложениями, содержащими прослои глин, 
Средний минеральный состав крупноалевритовой тяжелой фракции изученных отложений, \%

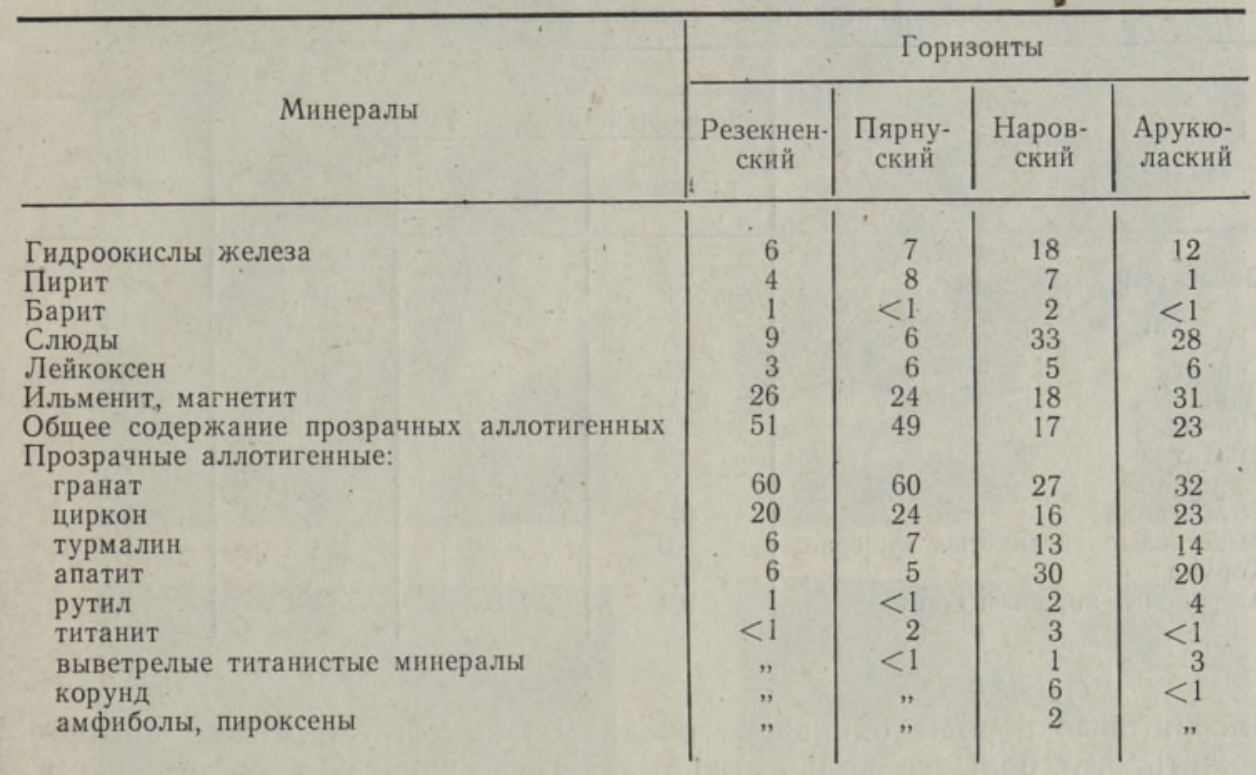

реже - алевролитов и песчаников (нижняя часть Наровского горизонта). Выше следует комплекс переслаивания алевролитов, домеритов и глин (верхняя часть Наровского горизонта), который венчается песчано-алевритовыми отложениями, содержащими редкие прослои глин и домеритов (Арукюлаский горизонт). '

В тяжелой фракции изученных отложений обычно преобладают черные рудные (ильменит, магнетит) или слюдистые минералы. Важнейшие прозрачные аллотигенные тяжелые минералы в различных уровнях - гранат, циркон, апатит, реже турмалин. Второстепенные рутил, титанит, ставролит, монацит, корунд, амфиболы и пироксены (Вийдинг, 1968; Клеесмент, 1969; табл. 1). При этом минеральный состав определяется не только стратиграфическим положением, но и литологическим типом конкретного образца. В тяжелой фракции карбонатных пород и глин обычно преобладают аутигенные минералы, особенно пирит и гидроокислы железа. Это связано с условиями седиментации и особенностями раннедиагенетического процесса в этих отложениях. В песчано-алевритовых отложениях (в тяжелой фракции) преобладают прозрачные аллотигенные минералы.

Существенные различия, наблюдаемые в количественных соотношениях тяжелых аллотигенных минералов в породах разных типов (табл. 2), только частично могут быть объяснены закономерностями селективной сортировки при отложении и переотложении кластического материала. Во многом они обусловлены постседиментационными преобразованиями.

Резко отличаются друг от друга терригенные и глинисто-карбонатные отложения по содержанию магнетита и ильменита. В алевритовой фракции глин и карбонатных пород в большинстве случаев среди черных рудных минералов доминирует магнетит. Он составляет $60-90 \%$ черных рудных минералов и в среднем 10,9\% тяжелой фракции. В терригенных отложениях, наоборот, всегда преобладает ильменит. Магнетит составляет не более $10-20$ рудных и в среднем $3,4 \%$ тяжелых минералов (табл. 2). Так как рыхлые и сцементированные песчано- 
Таблица 2

Средние минеральные составы некоторых тяжелых минералов

в крупноалевритовой фракции различных пород, \%

\begin{tabular}{|c|c|c|c|c|c|}
\hline & \multirow{3}{*}{ Мннералы } & \multicolumn{4}{|c|}{ Породы } \\
\hline & & \multicolumn{2}{|c|}{ песчаники, алевролиты } & \multirow[b]{2}{*}{ глины } & \multirow[b]{2}{*}{$\begin{array}{l}\text { домериты, } \\
\text { доломиты }\end{array}$} \\
\hline & & рыхлые & $\begin{array}{c}\text { сцементиро- } \\
\text { ванные }\end{array}$ & & \\
\hline Лейкоксен & & 7,5 & 5,3 & 2,9 & 2,0 \\
\hline Магнетит & & & & &, 9 \\
\hline $\begin{array}{l}\text { Гранат } \\
\text { Циркон } \\
\text { Турмалин } \\
\text { Апатит } \\
\text { Рутил } \\
\text { Титанит } \\
\text { Выветрелые } \\
\text { Корунд } \\
\text { Амфиболы, }\end{array}$ & $\begin{array}{l}\text { титанистые минералы } \\
\text { пироксены }\end{array}$ & $\begin{array}{r}27,5 \\
21,3 \\
17,3 \\
24,7 \\
4,1 \\
0,9 \\
4,0 \\
0,1 \\
0,4\end{array}$ & $\begin{array}{r}46,1 \\
13,8 \\
13,7 \\
21,4 \\
2,1 \\
2,6 \\
2,0 \\
0,4 \\
0,6\end{array}$ & $\begin{array}{r}48,5 \\
20,0 \\
8,0 \\
10,2 \\
3,0 \\
3,2 \\
2,2 \\
1,0 \\
2,1\end{array}$ & $\begin{array}{r}56,2 \\
.17,6 \\
5,9 \\
6,8 \\
1,7 \\
3,9 \\
1,8 \\
2,1 \\
2,6\end{array}$ \\
\hline
\end{tabular}

алевритовые породы одинаково обеднены магнетитом, можно предположить, что большее количество магнетита уничтожается именно в ранних стадиях литогенеза, по крайней мере, до катагенетической доломитизации. За счет магнетита возникали гидроокислы железа, частично продукты разложения магнетита участвовали в образовании цемента породы. Наблюдаемые закономерности вряд ли объяснимы процессами селективной сортировки при седиментации: магнетит тяжелее ильменита и должен выпадать раньше, было бы логичнее ожидать его концентрирования именно в прибрежных песчаных отложениях.

Количество лейкоксена в изученных отложениях меняется менее закономерно. Наблюдается сконцентрирование этого минерала в глинисто-карбонатных отложениях Резекненского и Пярнуского горизонтов, и в терригенных отложениях Наровского и Арукюлаского горизонтов. Последние обогащены, кроме лейкоксена, еще и малопрозрачными выветрелыми титанистыми минералами и полуразложенным ильменитом. Зерна ильменита с пятнами лейкоксена встречаются в породах всех изученных типов примерно в одинаковом количестве. Образование основной массы лейкоксена связано, по-видимому, с процессами поверхностного выветривания и начальными стадиями постседиментационных преобразований. В терригенных толщах Наровского и Арукюлаского горизонтов формирование части лейкоксена могло происходить за счет других титанистых минералов и в более поздней стадии постседиментационных преобразований (табл. 3).

В группе прозрачных тяжелых аллотигенных минералов наиболее существенным изменениям в постседиментационной истории отложений подвергались гранат, амфиболы, пироксены, эпидот и титанит. Интерес представляют также изменения корунда, дистена, ставролита и апатита (табл. 3).

Рис. 1. Характер поверхности зерен в сканирующем электронном микроскопе. 1 титанит, скв, Шкяуне, гл. 386 м, песчаник, $\times 200 ; 2-$ корунд, обн. Навести, песчаник с доломитовым цементом, $\times 1300 ; 3$ - ставролит, скв. Шкяуне, гл. 261 м, песчаник, $\times 3300 ; 4$ - дистен, скв. Шкяуне, гл. 261 м, песчаник, $\times 1300 ; 5-$ корунд, обн. Навести, песчаник с доломитовым цементом, $\times 3300 ; 6-$ корунд, обн. Навести, песчаник с доломитовым цементом, $\times 1300$. 


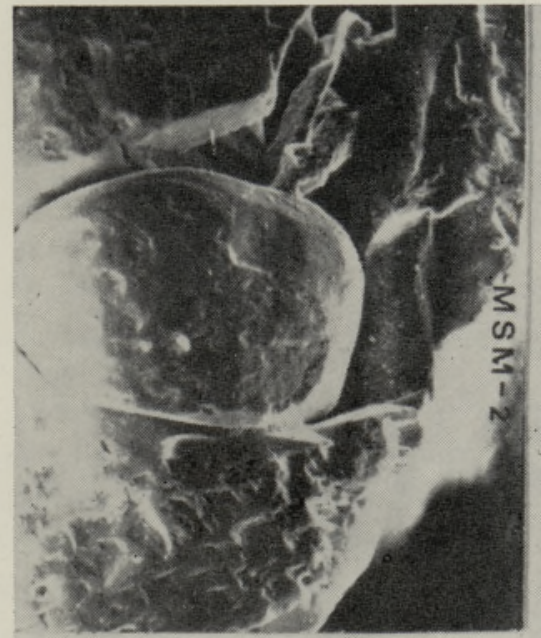

1

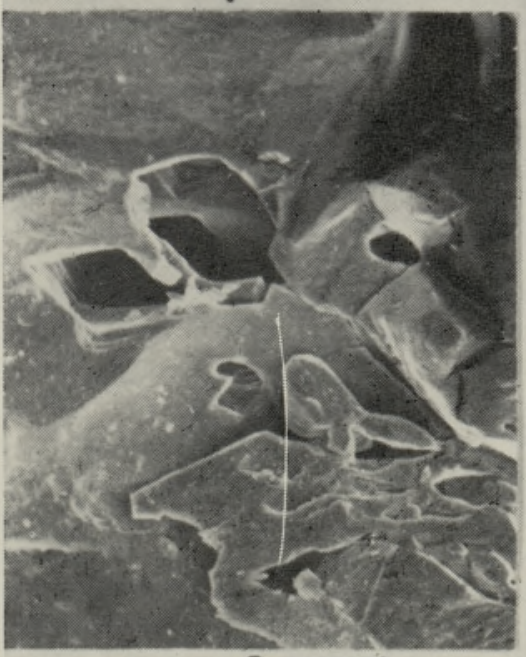

3

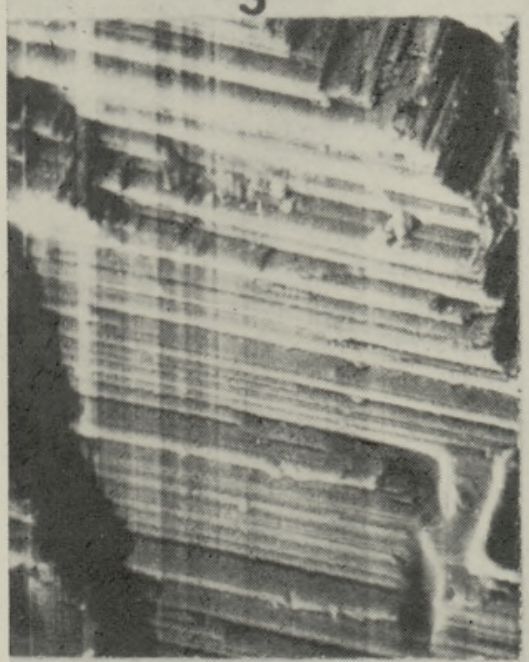
5
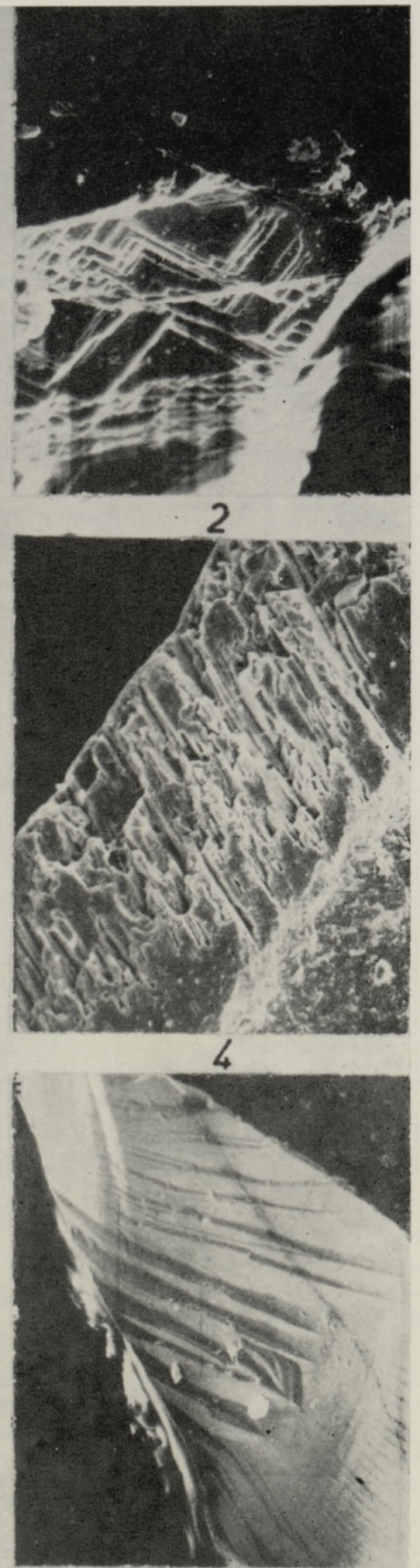

6 


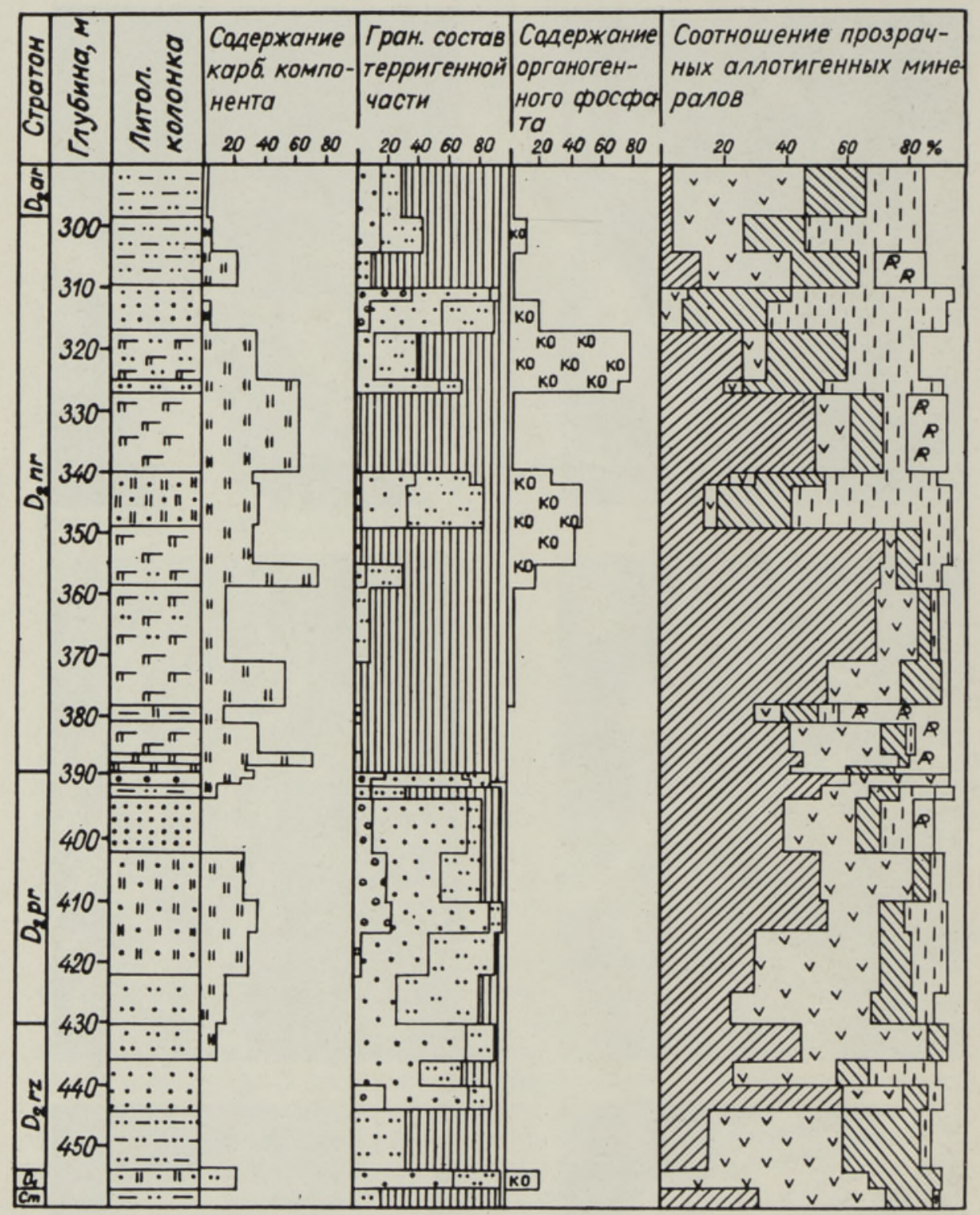

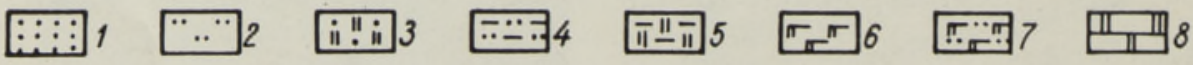

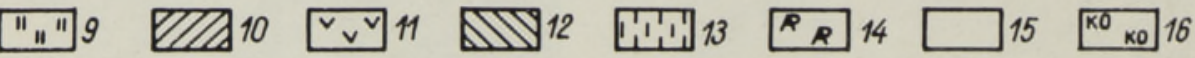

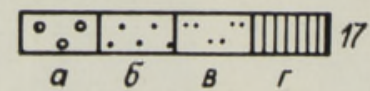

Рис, 2. Литолого-минералогический состав эйфельских отложений в скв. Луутснику. I - песчаник; 2 - алевролит; 3 - песчаник с доломитовым цементом; 4 - алевритовая глина; 5 - доломитовая глина; 6 - домерит; 7 - алевритистый домерит; 8 - доломит; 9 - доломитовый компонент; $10-$ гранат; $11-$ циркон; $12-$ турмалин; 13 - апатит; 14 - суммарное содержание амфнболов, пироксенов и эпидота; 15 - остальные тяжелые аллотигенные прозрачные минералы; 16 - фосфатные фрагменты организмов; 17 - гранулометрические фракцин: $a->0,25,6-0,25-0,1$, $8-0,1-0,01,2-<0,01$ мм. 
Основные процессы катагенетических преобразований тяжелых аллотигенных минералов в изученных отложениях

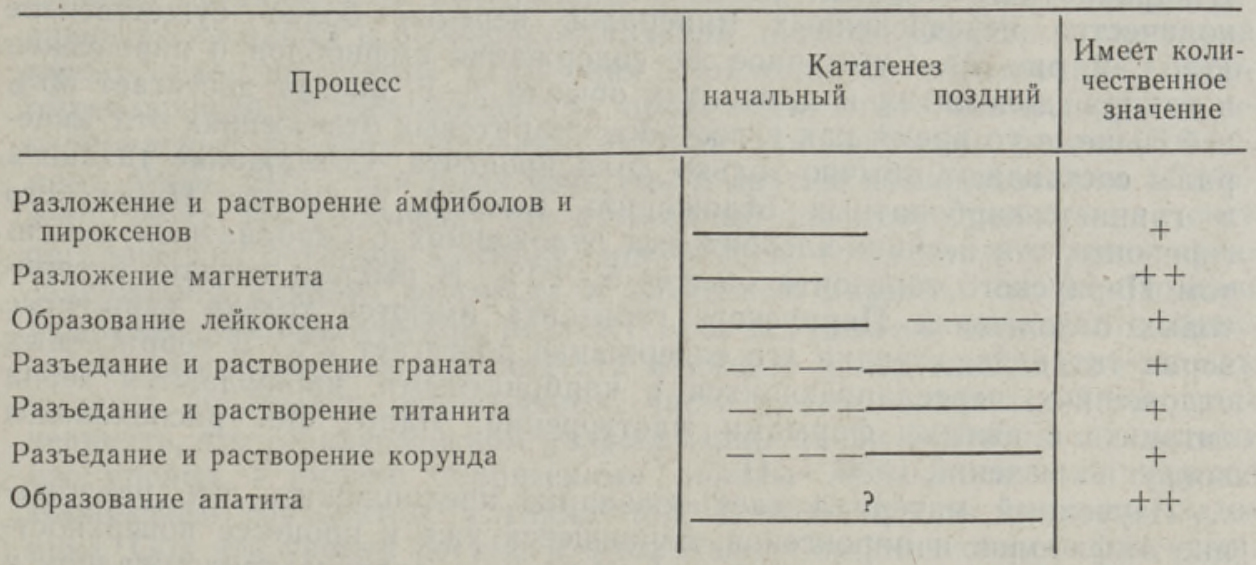

Закономерно, что содержание граната в карбонатных и глинистых породах изучаемого разреза заметно выше, чем в рыхлых песчаноалевритовых (табл. 2). Особенно большие различия в содержании граната в рыхлых песчано-алевритовых и глинисто-карбонатных породах в верхней части Наровского горизонта, где наблюдается частое переслаивание разнотипных пород (рис. 2). В карбонатных отложениях этой части разреза содержание граната $50-60$, в глинах $40-50$, в песчано-алевритовых отложениях с карбонатным цементом 35-45, в рыхлых терригенных отложениях 10-30\%. В Резекненских и Пярнуских отложениях, где в мощном песчано-алевритовом комплексе встречаются лишь редкие маломощные карбонатные прослои, различия в содержаниях граната в разнотипных породах менее резкие (рис. 2). Процессами селективной сортировки при перемещении, переотложении и аккумуляции вышеизложенные закономерности объяснить очень трудно: гранат в таком случае должен концентрироваться именно в наиболее грубозернистых терригенных отложениях.

Полученные данные позволяют предположить, что в период постседиментационных преобразований, особенно в их поздних стадиях, под влиянием активных межпластовых растворов растворялась часть зерен граната, что существенно влияло на количественные соотношения прозрачных аллотигенных минералов тяжелой фракции (Клеесмент, Паап, 1978). Особенно сильно растворялся гранат в разрезах с частым переслаиванием терригенных отложений с карбонатными и глинистыми. Қарбонатные породы могли повлиять на химизм этих растворов и повысить их агрессивность к гранату.

Интересные данные получены и при изучении особенностей поверхности зерен граната под сканирующим электронным микроскопом. Выяснилось, что для каждого из изученных типов пород характерны определенные типы рельефа поверхностных образований граната. Отчетливая корреляция между этими явлениями свидетельствует о том, что поверхность зерен граната несет ценную информацию об истории формирования изученных нами отложений и является важным индикаторным свойством данного минерала. Изученный нами материал указывает также на то, что большая часть поверхностных образований зерен граната в данных отложениях имеет постседиментационный генезис (Клеесмент, Паап, 1979).

На основе полученных данных можно предположить также, что 
титанит, амфиболы и пироксены частично растворялись в постседиментационной стадии истории отложений. В рыхлых песчано-алевритовых отложениях количество названных минералов весьма незначительно. В карбонатных отложениях и глинах, часто переслаивающихся с ними, количество перечисленных минералов нередко более существенное (табл. 2, рис. 2). Суммарное же содержание амфиболов и пироксенов в глинах, доломитах и домеритах обычно $2-5$, иногда достигает $30 \%$ и больше, в то время как в песчано-алевритовых отложениях эти минералы составляют обычно только доли.процента. Содержание титанита в глинисто-карбонатных отложениях нижней половины Наровского горизонта и в песчано-алевритовых отложениях с карбонатным цементом Пярнуского горизонта обычно 5-10\%. В рыхлых песчано-алевритовых отложениях Пярнуского горизонта имеются только единичные зерна титанита, изредка его содержание достигает $2 \%$. В терригенных отложениях, переслаивающихся с карбонатными, наблюдаются зерна титанита с явными формами растворения. Часто они расположены вокруг включений (рис. 1,1$)$.

Изученный материал дает основание предположить, что разложение амфиболов и пироксенов, начавшееся уже в процессе поверхностного выветривания и переотложения, весьма активно продолжалось и во время постседиментационных преобразований, что привело к частичному растворению этих минералов. Этот процесс в основном завершился в начальных стадиях катагенеза. Карбонатные прослои в терригенном комплексе способствовали развитию рассматриваемого процесса, очевидно, через гидрохимию внутрипластовых растворов. Разложение титанита продолжалось и в более поздних стадиях катагенеза, когда, по-видимому, происходило и основное его растворение (табл. 3).

В верхах изучаемого разреза, в верхней части Наровского и в Арукюласком горизонтах, в группе прозрачных аллотигенных тяжелых минералов встречаются также ставролит'и дистен, которые ниже по разрезу нехарактерны. В песчаных отложениях поверхность зерен ставролита и дистена обладает явными формами растворения (рис. 1, 3-4). Әти минералы сравнительно сконцентрированы в песчаноалевритовых породах. По изученному материалу трудно сказать, происходило ли полное растворение некоторых зерен названных минералов или только их корродирование.

Интересно, что заметное количество корунда - очень устойчивого в гипергенных условиях кор выветривания минерала - встречается только в хороших консервантах изученного комплекса - в глинах и доломитовых отложениях (табл. 2). Здесь корунд может составить более $10 \%$ всех прозрачных аллотигенных тяжелых минералов. В рыхлых песчано-алевритовых отложениях корунд весьма редок, но довольно часто встречается в песчаниках с базальным карбонатным цементом (до $5 \%$ ). Закономерно его присутствие в отложениях в ассоциации с малоустойчнвыми минералами - амфиболами, пироксенами, эпидотом. Эта особенность выявлена уже давно (Батурин, 1947), но до сих пор ей уделяли мало внимания. В изученных нами отложениях обнаружены интересные ступенчатые формы на поверхности зерен корунда (рис. 1,2, 5-6). Можно предположить, что в рыхлых песчаноалевритовых породах изучаемого разреза в постседиментационный период происходило сильное растворение зерен корунда, что привело к заметному уменьшению его количества в конечных породах (табл. 3).

Интересен по своему поведению также апатит. Обычно он концентрируется в мелкозернистых отложениях. В изученном разрезе, наоборот, апатит явно приурочен к песчано-алевритовым отложениям Арукюлаского горизонта и верхов Наровского, переслаивающимся с. глинами и прослоями карбонатных пород (рис. 2). Но и здесь содержа- 
ние апатита колеблется в широких пределах: большое количество минерала $(30-40 \%$ и более прозрачных аллотигенных тяжелых минералов) практически всегда наблюдается в прослоях, богатых фосфатными органическими фрагментами, либо залегающих на таких обогащенных органическим материалом уровнях. Обнаружены также признаки регенерации и перекристаллизации апатита. Обычно такие зерна имеют ориентированные включения. Аналогичные образования, сформировавшиеся за счет фосфатных органических остатков в терригеннокарбонатных породах ордовика Эстонии описаны нами ранее (Клеесмент, Мяги, 1975), они были известны и другим исследователям (Лебедева, 1962). Не исключено, что аутигенные апатиты, возникшие за счет органических остатков в осадке, значительно способствуют увеличению содержания данного минерала в изученном разрезе, что необходимо учитывать в практической работе. Пока не удалось определить количество такого аутигенного апатита в общей массе минерала, так как и зерна последнего, по-видимому, часто сильно окатаны. Стоит подчеркнуть, что в палеозойском разрезе Прибалтики апатитом обогащены два уровня, а именно терригенные породы Арукюлаского и верхов Наровского горизонтов, а также терригенные породы нижнего ордовика. Оба эти уровня богаты и фосфатными органическими остатками. Поэтому генезис апатита требует дальнейшего изучения. Пока он целиком рассматривается как аллотигенный, однако не исключено, что даже основная масса апатита в изученном разрезе возникла уже на месте, в терригенных отложениях, залегающих на карбонатном подстиле, который способствовал его аутигенезу. Не исключено также, что такой новообразованный апатит позже подвергся переотложению.

Проведенные исследования подтверждают, что в определенных условиях, в частности в комплексах с переслаиванием терригенных и карбонатных пород, в терригенных отложениях могут произойти существенные изменения, влияющие на количественные соотношения минералов. Эти изменения отражаются на составе тяжелых аллотигенных минералов (табл. 2,3 ), являющихся часто индикаторами для стратиграфических и палеогеографических реконструкций. Поэтому особенно важно правильно оценивать эти процессы. В рыхлых кластогенных отложениях, тесно переслаивающихся с карбонатными или глинистыми породами, содержание амфиболов, пироксенов, титанита, граната, а возможно, и корунда может значительно уменьшится, что обогатит эти отложения цирконом, турмалином и рутином. Возможно, что апатит в значительной мере вторичен. Значит, чтобы на основе минерального состава отложений установить характер области сноса, все это необходимо учесть и, по возможности, помимо терригенных пород, проанализировать минеральный состав.кластогенной части глинисто-карбонатных. Последний более близок к исходному материалу. При обработке минералогических данных в целях стратиграфии и корреляции разрезов также нужно учесть все эти изменения.

Изученный нами материал позволяет сделать некоторые выводы и о последовательности рассматриваемых изменений (табл. 3). В начальных стадиях постседиментационных преобразований продолжались начавшиеся уже в сфере седиментации процессы разложения магнетита, разложения и растворения амфиболов и пироксенов, образования лейкоксена. Эти изменения в основном завершились до ка́тагенетической доломитизации. Разъедание и растворение граната и титанита, наверняка, произошли в более поздних стадиях постседиментационных преобразований, главными факторами которых были время и влияние активных межпластовых растворов. Последнее весьма велико, как это подчеркивается и исследователями других регионов (Холодов, 1982). Время разъедания и растворения корунда пока не уточ- 
нено. По всей вероятно̄сти, этот процесс принадлежит к поздним стадиям катагенеза (табл. 3). Время формирования аутигенного апатита также не определено однозначно, но можно предположить, что этот процесс весьма длителен.

Таким образом, путем изучения явлений постседиментационных преобразований в минеральном составе отложений можно выявить индикаторные свойства минералов, важные для познания сущности н стадии катагенеза. Хорошими индикаторными свойствами обладают поверхностные образования на зернах граната (Клеесмент, Паап, 1979). Очевидно и значение поверхностных образований других минералов: титанита, корунда, ставролита и дистена, недостаточно изученных в наше время. Высказано даже предположение, что один из самых чувствительных индикаторов стадиальности катагенеза - титанит (Юркова, 1971). В изучаемом разрезе этот минерал, несомненно, заслуживает дальнейшего исследования.

\section{ЛИТЕРАТ УР А}

Батурин В. П. Петрографнческий анализ геологического прошлого по терригенным компонентам. М.-Л., 1947.

Bийдинг X. A. Литолого-минералогический состав и вопросы генезиса терригенных отложений девона Северной Прибалтики. - В кн.: Генезис и классификация осадочных пород. М., 1968, $75-81$.

Казанский Ю. П. Выветривание и его роль в осадконакоплении. М., 1969.

Казанский Ю. П. Седиментология. Новосибирск, 1976.

Клеесмент А. Э. Литология и литостратиграфия нижнего девона и эйфельского яруса $\left(\mathrm{D}_{2}\right)$ Эстонин. Автореф. канд. дис. Таллин, 1969.

Клеесмент A., Мяги С. К литологической и минералогической характеристике отложений цератопигевого и латорпского горизонтов Эстонской структурнофациальной зоны. - Изв. АН ЭССР. Хим. Геол., 1975, 24, № 1, 55-63.

Клеесмент А. Э., Паап Ю. А. О постседиментационных изменениях зерен граната. Лит. и полезн. ископ., 1978, № 5, 135-143.

Клеесмент А., Паап Ю. Характер поверхности зерен граната в девонских породах Прибалтики. - Изв. АН ЭССР. Геол., 1979, 28, № 1, 18-25.

Kопелиович A. B. Эпигенез древних толщ юго-запада Русской платформы. М., 1965.

Коссовская А. Г. Минералогия терригенного мезозойского комплекса Вилюйской впадины и западного Верхояна. М., 1962.

Лебедева А. И. О вторичных изменениях древнепалеозойских песчано-глинистых отложений северо-западной части Русской платформы, - Уч. зап. ЛГУ, сер. геол., 1962, № 310 .

Окнова $H . C . \mathrm{K}$ вопросу о распределении минералов по гранулометрическим фракциям. - ДАН СССР, 1972, 203, 921-923.

Холодов В. Н. Новое в познании катагенеза. - Лит. и полезн. нскоп., 1982, № 3 , $3-22$.

Юркова Р. М. Использование явления эпигенетического внутрислойного растворения некоторых акцессорных минералов для установления времени формирования нефтяных месторождений, - В кн.: Эпигенез и его минеральные индикаторы. M., 1971.

Andel, T. H. Reflections on the interpretation of heavy mineral analyses. - J. Sediment Petr., 1959, 29, 153-163.

Flores, R. M., Shidler, G. L. Factors controlling heavy-mineral variations on the South Texas outer continental shelf, Gulf of Mexico. - J. Sediment Petr., 1978, 48, 269-280.

Goldich, S. S. A study in rock weathering. - J. Geol., 1938, 46, 17-58.

Hubert, J. F., Reed, A. A. Red-bed diagenesis in the East Berlin Formation, Newark group, Connecticut Valley. - J. Sediment Petr., 1978, 48,' 175-184.

Morton, A. C. Depth control of intrastratal solution of heavy minerals from the Paleocene of the North Sea. - J. Sediment Petr., 1979, 49, 281-286.

Ннститут геологии

Академии наук Эстонской ССР
Поступила в редакцию 4/V 1983 


\section{SEKUNDAARSETE PROTSESSIDE MOJJU RASKETE ALLOTIGEENSETE MINERAALIDE SUHTVAHEKORRALE}

Raskete allotigeensete mineraalide suhtvahekorrad, mis on tihti olulised stratigraafiliste ja paleograafiliste tööde tegemisel, ei formeeru alati settekivimi kujunemisel, vaid muutuvad ka postsedimentaarses staadiumis, kui jätkub magnetiidi asendumine raudhüdroksiidiga. Pudedates purdsetetes, mis vahelduvad karbonaat- ja savikivimite kihtidega, toimub keemiliselt aktiivsete kihtidevaheliste lahuste möjul granaadi, titaniidi, amfiboolide, pürokseenide, võimalik et ka korundi osaline lahustumine; mille tulemusel nende mineraalide hulk kivimis väheneb. Samades tingimustes toimub fosfaatsete organismide regeneratsiooni ja ümberkristallumise tōttu autigeense apatiidi teke ning apatiidi osatähtsus kasvab tunduvalt. Geoloogiliste järelduste tegemisel on oluline nende protsesside kvantitatiivset mõju õigesti hinnata.

\section{Anne KLEESMENT}

\section{THE EFFECT OF SECONDARY PROCESSES ON THE RATIOS OF ALLOTHIGENIC MINERALS}

The ratios of heavy allothigenic minerals, which are often of great importance in stratigraphic and palaeographic investigations, have not always been formed during the development of the sedimentary rock, but they have also been subjected to changes at the post-sedimentary stage, during the replacement of magnetite by ferrohydroxide. In crumbly detritic sediments, which alternate with layers of carbonaceous and clayey rocks, there occurs a partial dissolution of garnet, titanite, amphiboles, pyroxenes and possibly also of corundum, due to the effect of the chemically active solutions occuring between the strata. As a result, the content of the above-mentioned minerals in the rock is bound to decrease.

Under the same conditions, owing to the regeneration and re-crystallization of phosphatic organisms, there occurs a generation of authigenic apatite, causing a considerable increase in the content of apatite in the rock. For drawing geological conclusions it is of utmost importance to estimate correctly the quantitative effect of the processes described above. 